\title{
Assessment of Performance Based Road Maintenance Practices in Nepal
}

\author{
Abhiman Das Mulmi \\ Department of Roads, Ministry of Physical Infrastructure and Transport, Government of Nepal, Kathmandu, \\ Nepal \\ Email: adammulmi@gmail.com
}

Received 29 February 2016; accepted 27 March 2016; published 30 March 2016

Copyright (C) 2016 by author and Scientific Research Publishing Inc.

This work is licensed under the Creative Commons Attribution International License (CC BY). http://creativecommons.org/licenses/by/4.0/

(c) (i) Open Access

\begin{abstract}
Roads are the major asset of any country and to conserve them maintenance is essential. The delay of maintenance works can lead the road in the stage of expensive rehabilitation and reconstruction. In Nepal, Department of Roads (DoR) is responsible for maintenance of strategic roads of country. The maintenance practice of the road under Department of Road is predominantly based on Strengthen Maintenance Division Process where several maintenance activities like Routine maintenance, Recurrent Maintenance, Periodic Maintenance and Emergency Maintenance are planned and carried out. The maintenance work is based on traditional quantity and unit price based short term maintenance contracts, where maintenance of physical works is outsourced. Client demands the contractor what work is to be done, when to be do it and the extent of the work. The contractor is paid on the basis of a defined output or quantity accomplished, and the schedule of the rates. DoR engineers required full time supervision of work. Pilot based performance based maintenance practice of road started in Nepal in 2003. The study assesses performance road maintenance practices of road maintenance in Nepal on the basis of the framework of cost efficiency, level of service effectiveness and quality of service. The study concluded that implementation of Performance Based Maintenance Contract (PBMC) was not successful in Nepal as Road Asset condition was not maintained to performance standard. One of the reasons is the weak service delivery of contractor alongside weak contract enforcement from the road agency.
\end{abstract}

\section{Keywords}

Road Maintenance, Performance Based Maintenance, Cost Efficiency, Contract Management

\section{Introduction}

Department of Roads (DoR) is main road authority in Nepal for the construction and maintenance of strategic 
road network (SRN). Up to 2013/014, Nepal has 12,494 km of Strategic Road Network. The total Strategic road network constitutes $3460 \mathrm{~km}$ of National Highways (NH), $6070 \mathrm{~km}$ of Major Feeder Roads (FRN), and $669 \mathrm{~km}$ of Minor Feeder Roads (FRO), 1032 km of Mid Hill Highway (MHH) and $632 \mathrm{~km}$ of Postal Road (PR). Around $6400 \mathrm{~km}$ of the SRN is black topped and the rest is gravel surface or earthen tracks [1]. The National Highway includes $1020 \mathrm{~km}$ of East-West Highway and North South Corridors. The traffic on the National Highway network ranges between 2000 - 5000 AADT. The most of the black-topped roads are two lane highways with a paved surface 6 - $10 \mathrm{~m}$ wide, consisting of surface dressing over granular base, with a limited length having an asphalt mix surface. The East West highway and the North South Corridor from Birgunj in South and Kodari in the North are the sections of Asian Highway. In Nepal, Road conditions are categorized on the basis of Surface Distress Index (SDI), IRI (International roughness index). A Visual survey of Surface Distress Index (SDI) carried out every two year to categorize the road conditions as good (SDI < 1.7), fair (SDI of $1.7-3.0$ ) or poor (SDI > 3.0). Based on SDI survey of 2013/14 $5800 \mathrm{~km}$ of the SRN infers 57\% in good condition, 31\% in fair condition and $11 \%$ in poor condition [2].

The Priority Investment Plan (PIP) has showed that Nepal is losing the value of $\$ 1$ billion due to the lack of proper maintenance works [3]. Overall maintenance expenditure estimated by PIP (From 2007 to 2016) is Rs31.2 billion, representing 28 percent of the total that includes upgrading and the new construction. Regular Annual Maintenance (Rs11.1 billion) is calculated on a per km basis for a network length increasing from 7360 $\mathrm{km}$ in 2007 to $9930 \mathrm{~km}$ in 2016, plus a continuing allowance for non-SRN roads maintained by DoR. The Periodic Maintenance is estimated at Rs20 billion referring to a network of $9700 \mathrm{~km}$, plus an allowance for the additional road length and on-going bridge maintenance [3]. But this budget requirement as identified by the PIP is not fulfilled each year. Maintenance management of the road is predominantly based on Strengthen Maintenance Division Process, which identifies routine, recurrent, periodic and emergency maintenance as the maintenance activity. All these maintenance activities are short-term and carried out through the short term contract with the contractor. Contractors do their work and are paid in the schedule of rate basis. Once the work is completed, contractors get the completion certificate and then they either leave or have least liability toward the completed work. The same goes for annual process of procurement. Construction starts the next year. The data show that contractor seldom returns to the work after completion for the correction of work. The road agency is more engaged in the procurement work and cost overhead is also high. Pilot performance based maintenance concept was imported in Nepal in 2003 by World Bank as an alternative maintenance approach sought the greater role of the contractor. Road Maintenance Contracts based on PBM have its own problems and challenges. PBM contracts are said to be imposed in Nepal by Donors without the appropriate preparation. The study will assess the performance based maintenance management practice in Nepal in term of cost, quality and service effectiveness.

\section{Road Maintenance Practice in Nepal}

Nepal Road Maintenance activities are primarily based on Strengthened Maintenance Divisions Program (SMDP) and performance based maintenance practice.

\subsection{Strengthened Maintenance Divisions Program (SMDP) Practice}

The Strengthened Maintenance Divisions Program (SMDP) was initiated in 1993 as a two year pilot project in two DOR Divisions after experiences made on road maintenance tested along the Lamosangu-Jiri Road. Phase I started in 1995 with the aim of developing a maintenance management system suitable for the maintenance of SRN in a planned way [4]. During Phase II (1998-2002) the Strengthened Maintenance Divisions (SMD) process was gradually expanded and covered 23 Maintenance Divisions. The phase III starting in July 2002, incorporate 2 remaining Divisions achieving ability to prepare ARMP by all 25 Division Road Offices (DROs) along with rational financial management in terms of budget heads and funding has been established. Phase III come to an end in June 2006 [4]. Thorough three phases, the SMD process was successfully introduced in 25 Maintenance Divisions with the assistance of SDC. The SMDP road maintenance management is based on planned maintenance system which mainly contain; Routine Maintenance, Recurrent Maintenance, Periodic Maintenance and Emergency Maintenance. (See Figure 1) Allocation of the annual divisional maintenance budget is mainly done on the basis of the Annual Road Maintenance Plan (ARMP) introduced by SMDP. DRO first prepared the Divisional level ARMP. Regional level ARMP is made by integrating Divisional level ARMP under its region through conducting a regional workshop. Afterward Intergrated Annual Road Maintenance Plan 
A. D. Mulmi

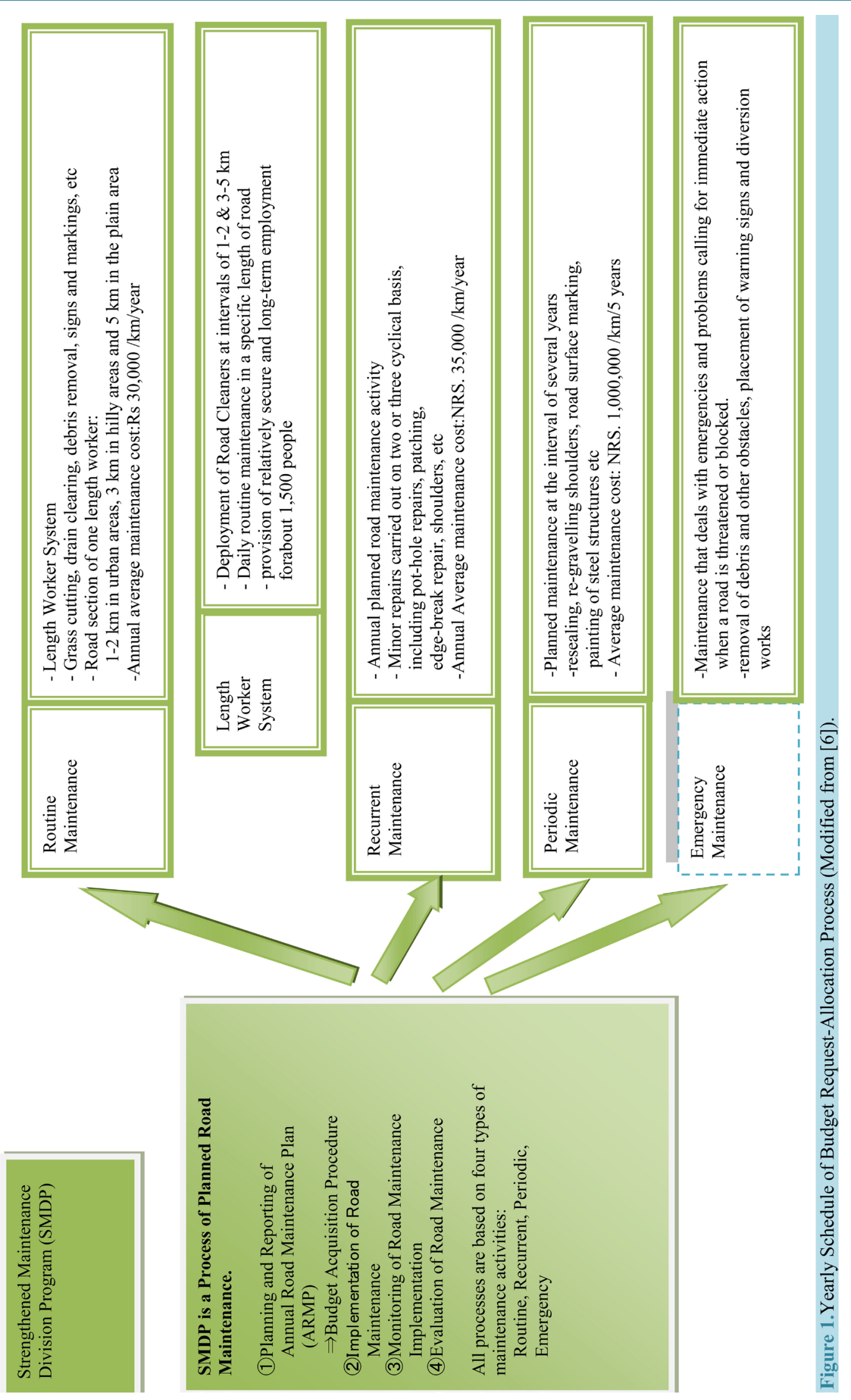


(IARMP) workshop is held to integrate the ARMP of all 25 Divisions under Department of Roads. Budget is allocated on the basis of priority of IARMP. ARMP process is shown in Figure 2 [4].

\section{Modality of Contract Implementation of Maintenance under SMDP}

All the Maintenance activities defined in the SMDP process are carried out on the basis of short term schedule item rate contract, where contract perform the work as per the Bill of Quantities. After completion of the work, contractor gets the work completion certificate and there is not proper mechanism to monitor the work of the contractor afterward. The modality often brings improvement over force account maintenance practices; the results are in many cases still less than optimal. The problem is that the contractor has the wrong incentive which is to carry the maximum amount of works in order to maximize his profit. Under this modality, a lot of work is carried out and much money spend the overall service quality for the road users depends on the quality of the design given to the contractor who is not accountable for it [5]. In the entire maintenance contract under SMDP, DoR Engineers are directly involved from procurement to the implementation. There is no consultant outsource for the supervision of the construction work under maintenance contract. Contractor was selected on the basis of the lowest competitive bidding.

\subsection{Performance Based Maintenance Contract (PBMC)}

Performance-Based Maintenance Contracting (PBMC) is a contracting method that provides incentives and/or disincentives to the contractor to achieve desired outcomes or results; in its purest form, PBMC does not detail how, when, or where to do the work [7]. A PBM contract is an agreement between a government department and a private contractor whereby the private contractor maintains the road to achieve specified condition standards for a certain period of time in return for a fixed payment stream. Under the contract the existing road would be maintained on the basis of customer-based performance indicators, such as riding and strength quality, safety features, and roadside aesthetics. This allocates higher risk to the contractor compared to traditional contract arrangements, but at the same time opens up opportunities to increase his margins where improved efficiencies and effectiveness of design, process, technology or management are able to reduce the cost of achieving

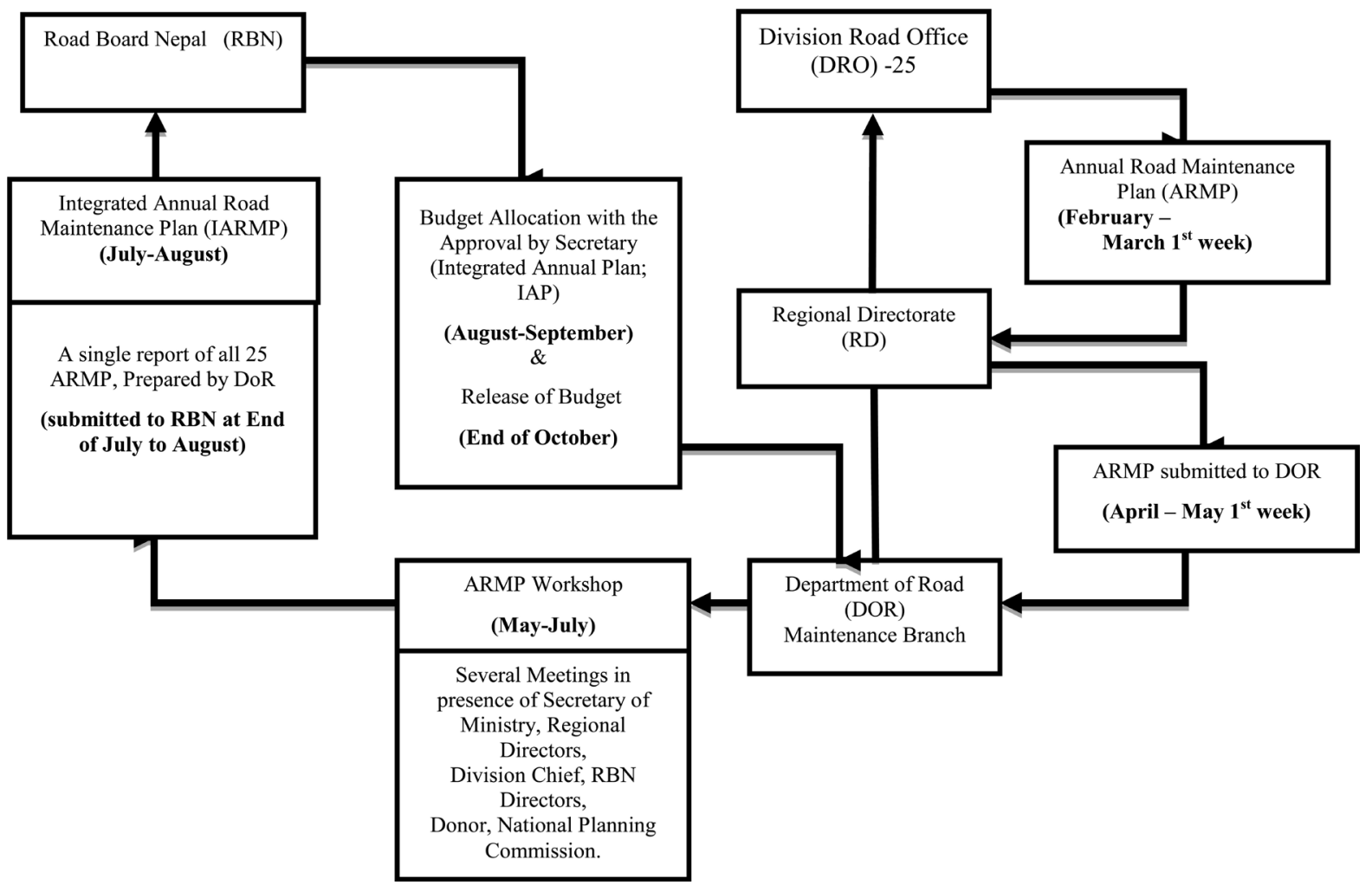

Figure 2. Yearly schedule of budget request-allocation process (modified from [6]). 
the specified performance standards [8]. The traditional method based specified maintenance contracts follow the construction-reconstruction cycle. While the performance based contracting ensure the road asset condition consistent and performing over the long period of time (Figure 3).

Under Performance-Based Road Management and Maintenance Contracts minimum conditions of road, bridge, and traffic assets that have to by the contractor, as well as other services such as the collection and management asset inventory data, call-out and attendance to emergencies, and response to public requests, complaints and feedback are well defined. Payments are based on how well the contractor manages to comply with the performance standards defined in the contract, and not amount of works and services executed [8].

The possible benefits for the implementation of the of PBMC mentioned in [9] are savings of cost for road maintenance works, risk sharing and assurance of quality by the contractor introduction of innovation, increasing the efficiency of the road authority and contractors, reducing the administrative burden, user satisfaction, achieving a sustainable road management system, increasing the flexibility of work, and increasing transparency and reducing the chance of corruption.

\section{Performance Based Maintenance Contract Modality in Nepal}

The first pilot based Performance Based Maintenance Contract started in June 2003 under the Road Maintenance and Development Program (RMDP) supported by IDA (International Development Association) in June 2003. The duration of the contract is only 2 years. 3 Contracts under RMDP/IDA and 5 Contracts under Road Network Development Program (RNDP) supported by Asian Development Bank (ADB) were implemented in Nepal as Performance Based Maintenance Contract. The Road and its details where PBMC implemented are listed in Table 1.

The Performance based management and maintenance contracts in Nepal generally comprises of General works, Maintenance works, Improvement works, Emergency woks, Day works (Figure 4). Out of the above works, Improvement works are planned to be completed in first two years while maintenance works planned in

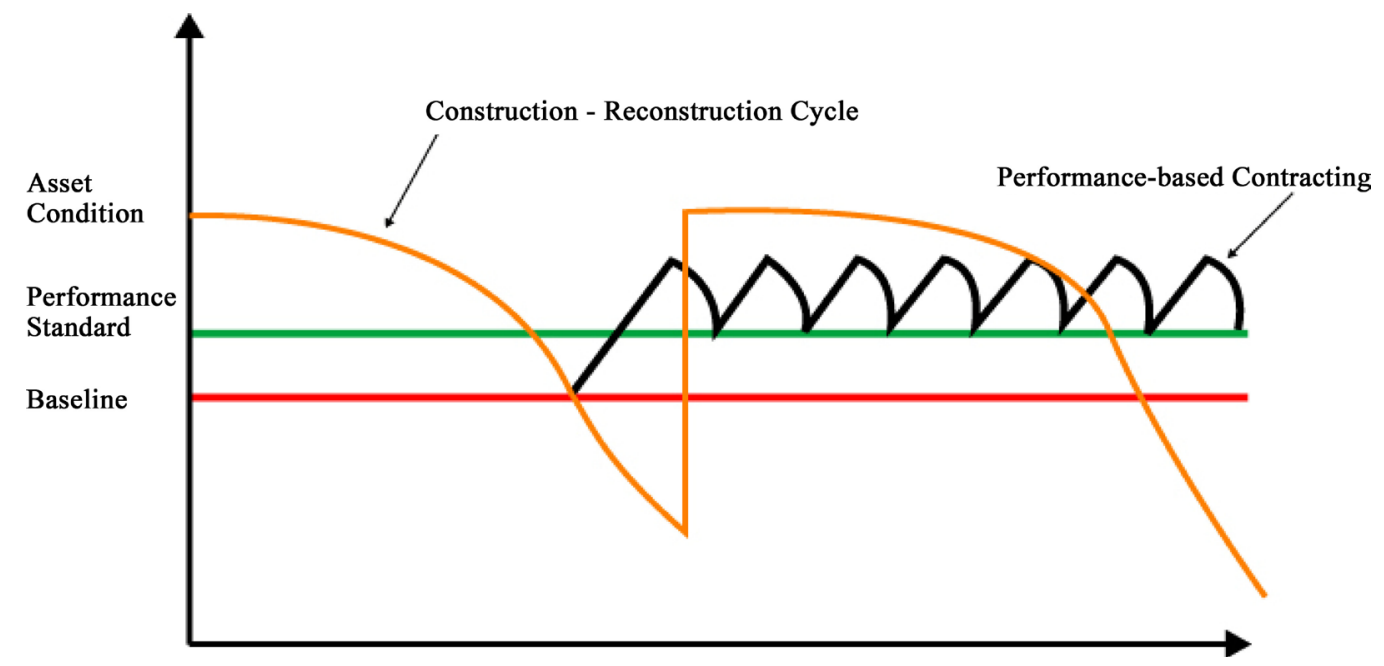

Figure 3. Asset condition under the traditional and performance based contracting.

Table 1. Performance Based Maintenance Contracts in Nepal.

\begin{tabular}{|c|c|c|c|c|c|c|}
\hline Name of Road & $\begin{array}{l}\text { Total } \\
\text { length }\end{array}$ & $\begin{array}{l}\text { Funding } \\
\text { Project }\end{array}$ & Duration & Starting year & Status & Contract Name \\
\hline $\begin{array}{l}\text { East West Highway (Pilot } \\
\text { PBMC in Nepal) }\end{array}$ & $114 \mathrm{~km}$ & RMDP/IDA & 2 years & 2003 June & Completed & Not Included in Study \\
\hline Chaurhawa-Pathlaiya & $150 \mathrm{~km}$ & RMDP/IDA & 5 years & 2005 April & Completed & $\begin{array}{l}\text { RMDP/PBMC/ICB01, } \\
\text { RMDP/PBMC/ICB02 }\end{array}$ \\
\hline Hetauda Narayani Bridge & 78 km & RNDP/ADB & 5 years & Jan 2007 & Completed & RNDP/ICB/HN \\
\hline Kohalpur-Gaddachowki & 203 km & $\mathrm{RNDP} / \mathrm{ADB}$ & 5 Years & 2005 Sep & Completed & $\begin{array}{l}\text { RNDP/LCB/PBM1, RNDP/LCB/PBM2, } \\
\text { RNDP/LCB/PBM3, RNDP/LCB/PBM4 }\end{array}$ \\
\hline
\end{tabular}




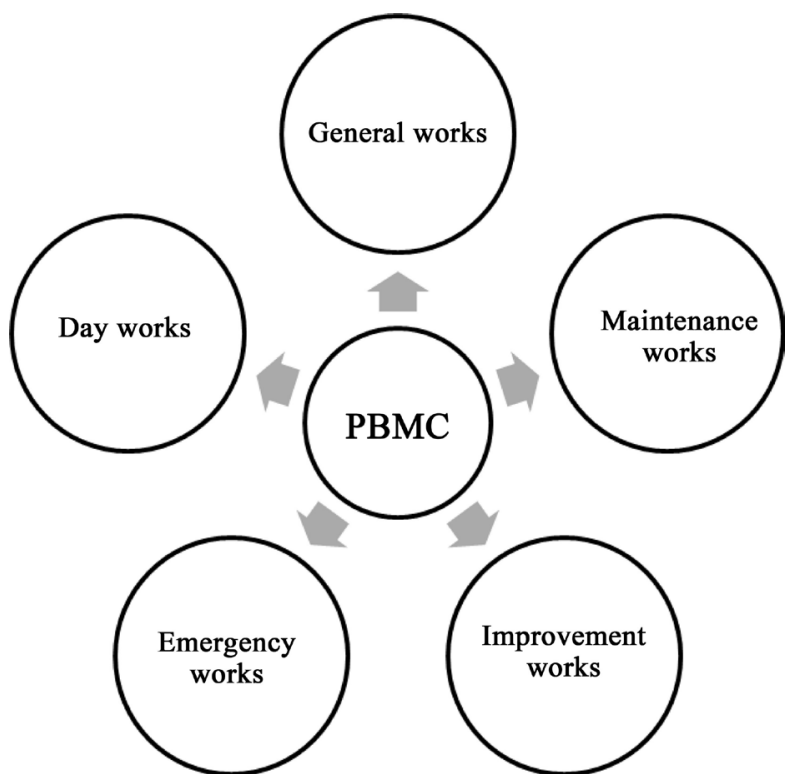

Figure 4. Different works under the Performance Based Maintenance and Management Contract of Nepal [5].

final three years of the project. Performance Based Maintenance Contract in Nepal allows the bidders to compete for a fixed monthly lump sum fee per km of road for the maintenance of the road. The Contractors are not paid directly for the inputs but are paid for the output like the initial rehabilitation works to the predefined standards. The monthly lump sum remuneration paid to the contractor cover all physical and nonphysical maintenance service provided by the contractor except for the unforeseen emergency works which are remunerated separately. Improvement works are rehabilitation works which have been explicitly specified by the employer in the contract would be quoted on the basis of the measurable output quantities and paid as performed. In order to be entailed to the monthly payment for the maintenance services, the contractor must ensure that the roads under contract comply with the service quality levels which have been specified in the bidding document [5]. The Contract modality hence is not completely output based as the Bill of quantities on all above contracts contain the item of works and the contractor quote the rate for each item to compete for the bid. The PBM modality in Nepal only difference from the traditional contract, is that it specified the minimum service quality level as the desired outcome for payment in the maintenance part. The Performance Based Maintenance Contract modality in Nepal and its characteristics is shown in Figure 5. The DoR directly supervise the PBMCs in the same way as in SMDP Maintenance Contract.

A questionnaire regarding Performance Indicators and format of service quality inspection was distributed among the 30 engineers having experience working in Performance Based Maintenance Contract Result has been shown in Figure 6. 60\% of the Road Engineers suggested for the modification of the service quality inspection format of the service quality inspection format compatible to the Nepali Environment.

Payment to the contractor for performance based maintenance is made is $100 \%$ only for $100 \%$ compliance with service quality level after formal inspection. Payment reductions for non compliance with service level quality as determined on the basis of evaluation. Payments for each kilometer of road each month is the rate in the Bill of Quantities multiplied by the coefficient of compliance. Besides, the following reductions in the contractor's interim certificate are applied for the non-compliance of service quality on the following items.

Result of survey among the Engineer working in PBMC regarding Payment reduction provision is shown in Figure 7. 4 Nos (13\% of respondent) acknowledges the Penalty and Payment reduction provision provided in the current PBM contract. 10 Nos of respondent (33\%) are just satisfied with the Penalty and Payment reduction provision made in the contract. Likewise, 16 Nos (54\% of respondent) believes that the provisions of penalty reduction made in contract are not compatible and need modification.

\section{Framework for Assessment of Road Maintenance Practice in Nepal}

A basically five analysis components have been identified and defined to analyze the performance based a 


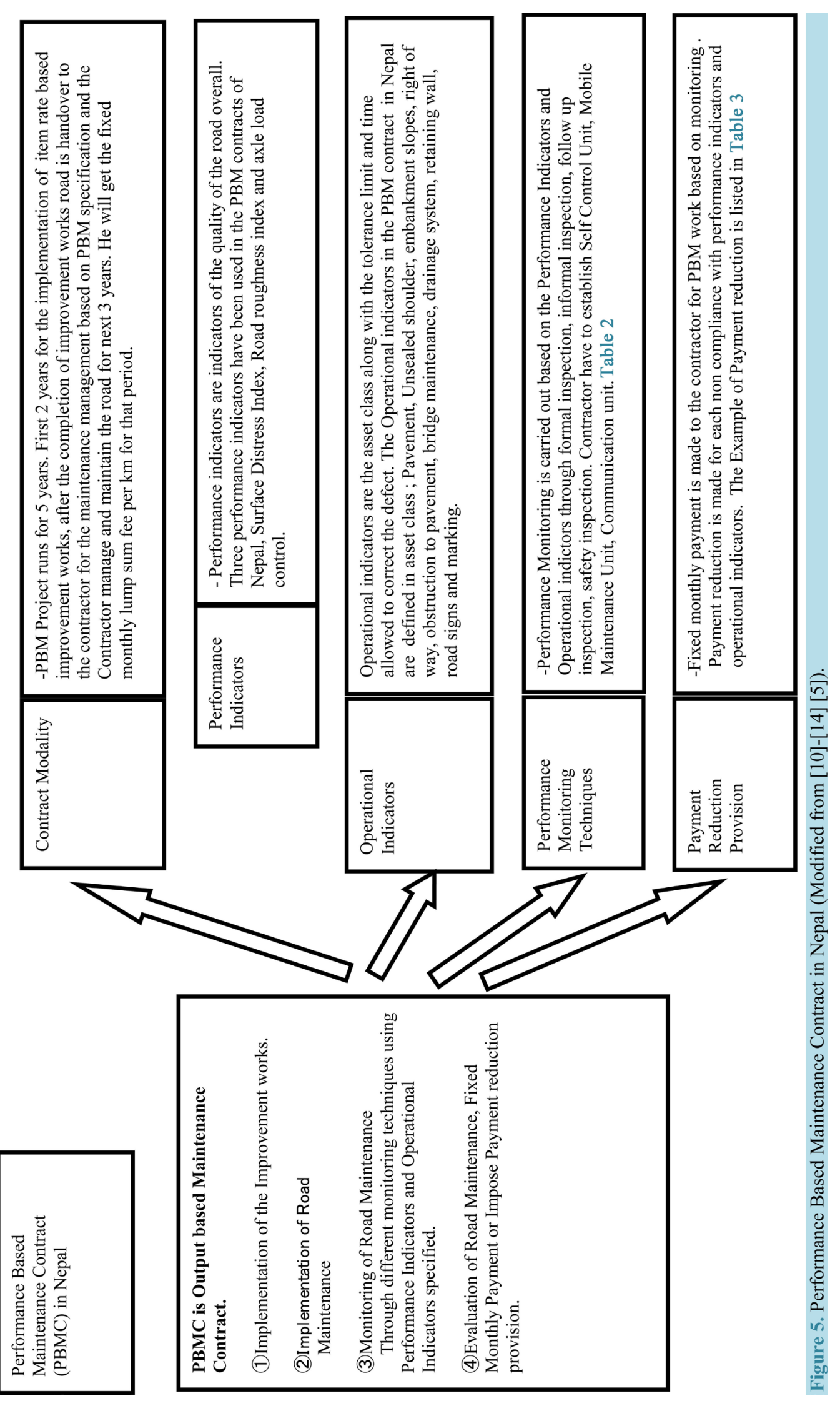


Table 2. Service quality evaluation for $1 \mathrm{~km}$ section of the road [5].

\begin{tabular}{|c|c|c|c|c|c|c|c|c|}
\hline \multirow[t]{2}{*}{ Aspect } & $\begin{array}{c}1 \\
(0+200)\end{array}$ & $\begin{array}{c}2 \\
(0+400)\end{array}$ & $\begin{array}{c}3 \\
(0+600)\end{array}$ & $\begin{array}{c}4 \\
(0+800)\end{array}$ & $\begin{array}{c}5 \\
(0+1000)\end{array}$ & $\begin{array}{l}\text { Number of non } \\
\text { complying } \\
\text { segments }\end{array}$ & $\begin{array}{l}\text { Weight } \\
\text { Factor }\end{array}$ & $\begin{array}{c}\text { Percentage of } \\
\text { non } \\
\text { compliance }\end{array}$ \\
\hline & \multicolumn{5}{|c|}{ Insert $\mathrm{X}$ if a segment does not comply } & (1) & (2) & $(3)=(1) \times(2)$ \\
\hline \multicolumn{9}{|l|}{ (A) Pavement/shoulder/roadside } \\
\hline Patch work & $\sqrt{ }$ & $\sqrt{ }$ & $\sqrt{ }$ & $\sqrt{ }$ & $\mathrm{x}$ & 1 & 10 & 10 \\
\hline Cracks/rutting/raveling & $\sqrt{ }$ & $\sqrt{ }$ & $\sqrt{ }$ & $\sqrt{ }$ & $\mathrm{x}$ & 1 & 6 & 6 \\
\hline Pavement edge break & $\sqrt{ }$ & $\sqrt{ }$ & $\mathrm{x}$ & $\sqrt{ }$ & $\sqrt{ }$ & 1 & 6 & 6 \\
\hline Cleanliness & $\sqrt{ }$ & $\sqrt{ }$ & $\sqrt{ }$ & $\sqrt{ }$ & $\sqrt{ }$ & 0 & 3 & 0 \\
\hline Shoulder & $\sqrt{ }$ & $\sqrt{ }$ & $\sqrt{ }$ & $\sqrt{ }$ & $\sqrt{ }$ & 0 & 4 & 0 \\
\hline Embankment slopes & $\sqrt{ }$ & $\sqrt{ }$ & $\sqrt{ }$ & $\sqrt{ }$ & $\sqrt{ }$ & 0 & 4 & 0 \\
\hline Vegetation control & $\sqrt{ }$ & $\sqrt{ }$ & $\mathrm{x}$ & $\sqrt{ }$ & $\sqrt{ }$ & 1 & 3 & 3 \\
\hline Obstruction on road & $\sqrt{ }$ & $\sqrt{ }$ & $\sqrt{ }$ & $\sqrt{ }$ & $\sqrt{ }$ & 0 & 2 & 0 \\
\hline Sub total (A) & & & & & & & 38 & 25 \\
\hline \multicolumn{9}{|l|}{ (B) Bridges and structures } \\
\hline Bridge maintenance & $\sqrt{ }$ & $\sqrt{ }$ & $\sqrt{ }$ & $\sqrt{ }$ & $\sqrt{ }$ & 0 & 7 & 0 \\
\hline Retaining and protection wall & $\sqrt{ }$ & $\sqrt{ }$ & $\sqrt{ }$ & $\sqrt{ }$ & $\sqrt{ }$ & 0 & 7 & 0 \\
\hline Waterway maintenance & $\sqrt{ }$ & $\sqrt{ }$ & $\sqrt{ }$ & $\sqrt{ }$ & $\sqrt{ }$ & 0 & 6 & 0 \\
\hline Sub total (B) & & & & & & & 20 & 0 \\
\hline \multicolumn{9}{|l|}{ (C) Drainage system } \\
\hline Longitudinal drains & $\sqrt{ }$ & $\sqrt{ }$ & $\sqrt{ }$ & $\sqrt{ }$ & $\sqrt{ }$ & 0 & 4 & 0 \\
\hline Culverts and cause ways & $\sqrt{ }$ & $\sqrt{ }$ & $\sqrt{ }$ & $\sqrt{ }$ & $\sqrt{ }$ & 0 & 10 & 0 \\
\hline Sub Total (C) & & & & & & & 14 & 0 \\
\hline \multicolumn{9}{|l|}{ (D) Signaling and road safety } \\
\hline Sign maintenance & $\sqrt{ }$ & $\sqrt{ }$ & $\sqrt{ }$ & $\sqrt{ }$ & $\sqrt{ }$ & 0 & 6 & 0 \\
\hline $\begin{array}{l}\text { Kilometer/delineators/guideposts/ } \\
\text { confidence blocks }\end{array}$ & $\sqrt{ }$ & $\sqrt{ }$ & $\sqrt{ }$ & $\sqrt{ }$ & $\sqrt{ }$ & 0 & 4 & 0 \\
\hline Road marking & $\mathrm{X}$ & $\sqrt{ }$ & $\sqrt{ }$ & $\sqrt{ }$ & $\sqrt{ }$ & 1 & 8 & 8 \\
\hline Sub total (D) & & & & & & & 18 & 8 \\
\hline $\begin{array}{l}\text { (E) Provision of maintenance } \\
\text { services }\end{array}$ & \multirow{2}{*}{\multicolumn{6}{|c|}{ Sub total (E) }} & 10 & 0 \\
\hline Total A + B + C + D + E & & & & & & & 100 & 33 \\
\hline
\end{tabular}

Table 3. Payment reduction provisions [5].

\begin{tabular}{ll}
\hline Potholes & Rs 1000.00/day/pothole \\
Obstructions in pavement causing road blocks & Rs 2000.00/hour/occurrence \\
Structure damage under PBM threatening stability & Rs 1000.00/day/occurrence \\
Blocked drains & Rs 250.00/meter/day \\
Blocked culverts & Rs 500.00/culvert/day \\
Non Compliance with Performance standards for SDI and IRI & $10 \%$ of the PBM monthly payment for kilometer \\
Noncompliance for allow of vehicle in excess of 10.2 t & NRs 1000 per vehicle
\end{tabular}

maintenance and management contract which has been currently practiced. Pinero J.C, 2003 [15] defined the key components of the framework for the assessment of performance based contracts as Timeliness of response, Quality of service, Safety procedures, Cost efficiency and Level of service. For this research purpose, I have selected three components for the analysis of the Performance Based Maintenance and Management Contracts in Nepal they are shown in Figure 8. 


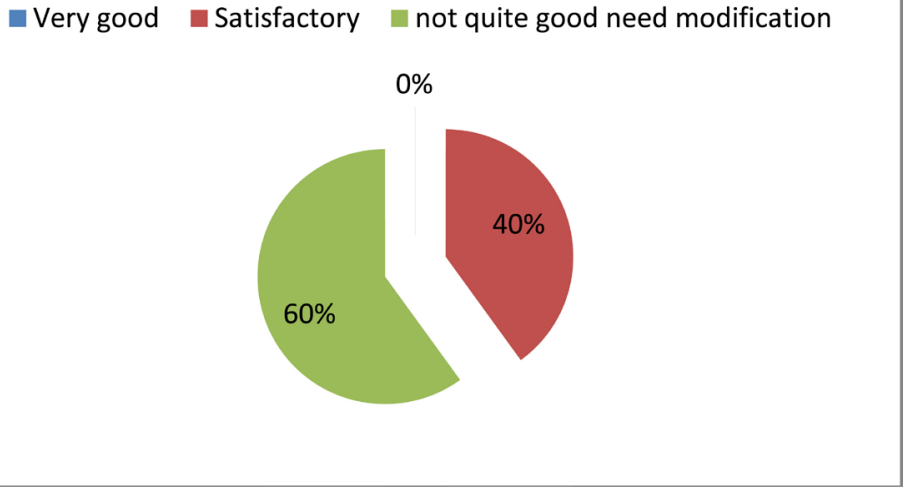

Figure 6. Present format of service quality inspection.

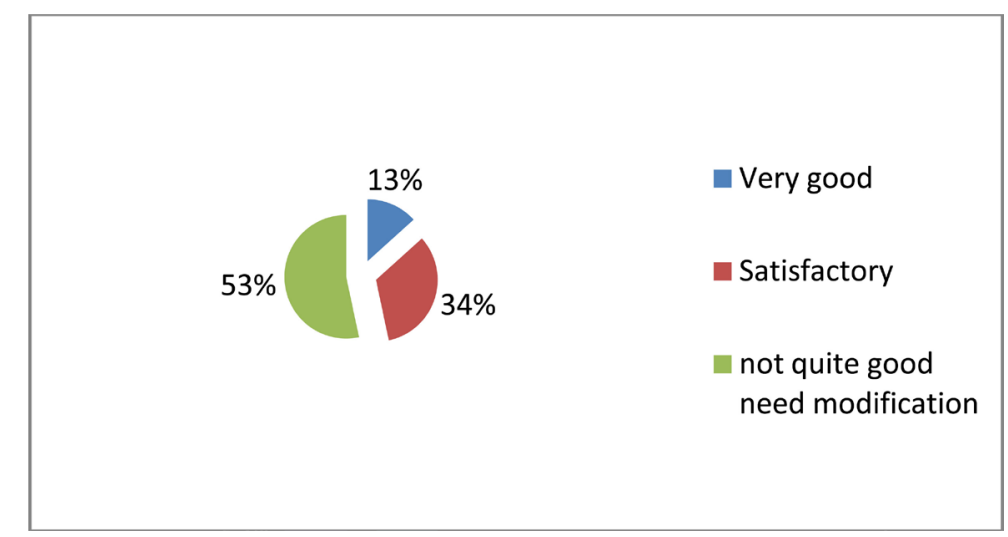

Figure 7. Payment reduction provisions made in PBM contract.

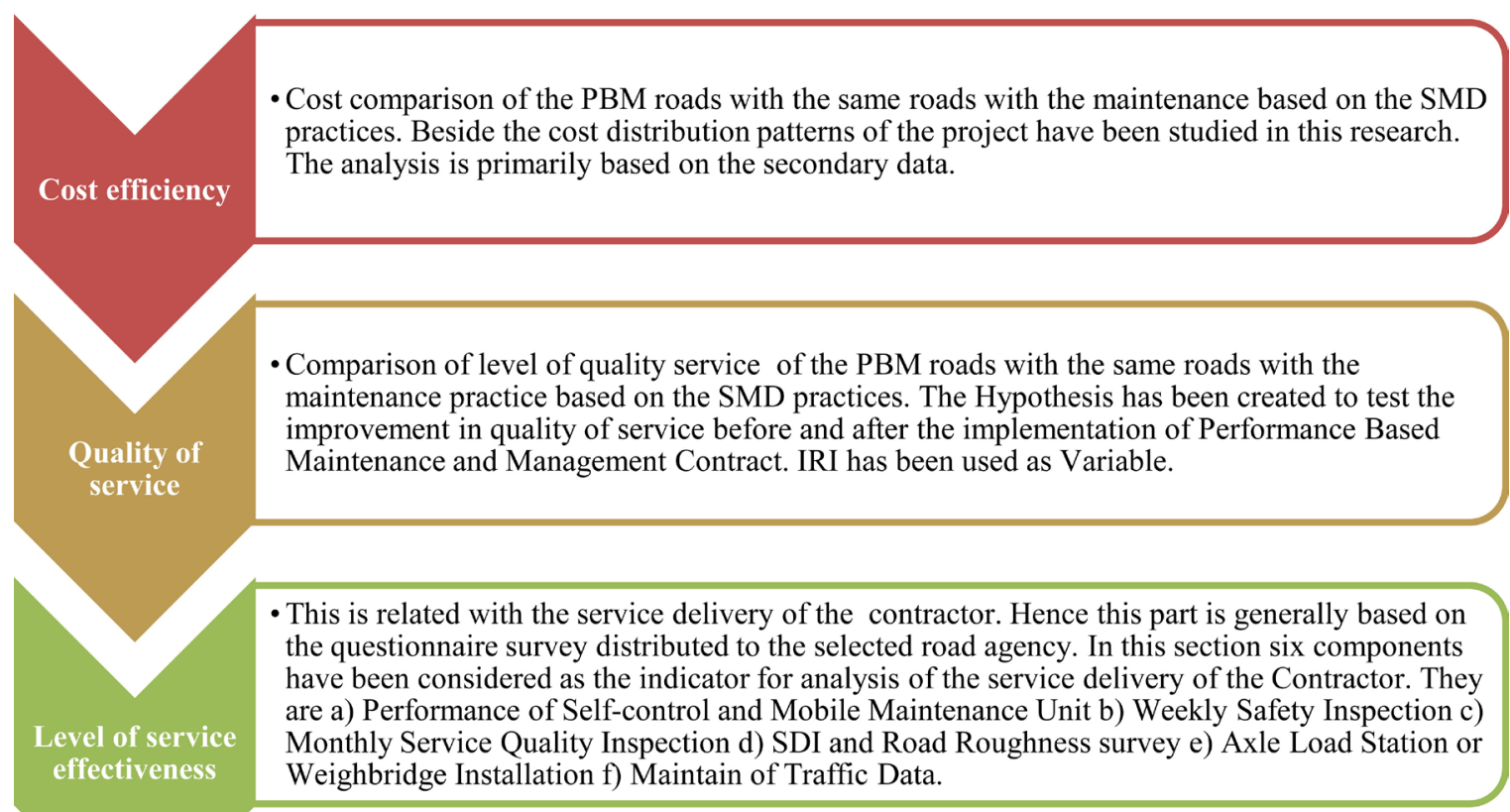

Figure 8. Framework for assessment of Performance Based Maintenance Contracts in Nepal. 


\subsection{Level of Service Effectiveness}

In this section six components as mention above have been considered as the indicator for analysis the service delivery of the Contractor. The success of the PBM project depends on how well the contractor performs the above listed component. Table 4 and Table 5 show the service delivery of contractor.

The data shows that Out of the seven running projects. In six projects, Contractor has set up the self control and mobile maintenance unit. However, they are not well performing. Self control and mobile maintenance unit is not established in one of the running project. Likewise, in six running project, contractor only carried out safety inspection of the road only occasionally in direction of Project Manager. In one of the project, it has not been carried yet. None of the project carried the weekly safety inspection regularly. Similarly, in six running project out of seven, Contractor carried out the Monthly Service Quality Inspection only occasionally in direction of Project Manager. In none of the project, the contractor has carried out the inspection regularly. In one of the project it has not been carried out yet.

In all projects, Contractor has carried out the Road roughness and SDI survey but it was not carried out regularly. Likewise, in only two projects, contractor has installed the Weighbridge where as in six project weighbridge has not been installed yet. Similarly, in all seven running project, the contractor has not maintain traffic data. The data shows that Contractors have not performed well in any of the six components for analyzing level of service effectiveness. A result of survey conducted among the 30 DoR engineers working in PBM regarding the performance and attitude of the Contractor shown in Figure 9. 60\% (18 Nos) of the respondent believes that Performance of Contractor is not satisfactory and they agree that Contractor is focus on earning the profit out of the improvement component of the PBM contract, and escape out of the responsibility and risk associated with the performance based maintenance in the later part of the contract. 12 Nos $40 \%$ of the respondent partially accepts it. No one say that the performance of contractor is good.

Table 4. Service delivery of contractor; maintenance unit, safety inspection and service quality inspection.

\begin{tabular}{|c|c|c|c|c|c|c|c|c|c|}
\hline \multirow[b]{2}{*}{ Contract Name } & \multicolumn{3}{|c|}{ Self control and mobile unit } & \multicolumn{3}{|c|}{ Weekly safety inspection } & \multicolumn{3}{|c|}{ Monthly service quality inspection } \\
\hline & $\begin{array}{c}\text { Well } \\
\text { perform }\end{array}$ & $\begin{array}{l}\text { Not well } \\
\text { perform }\end{array}$ & $\begin{array}{c}\text { Not } \\
\text { establish }\end{array}$ & $\begin{array}{l}\text { Carried } \\
\text { regularly }\end{array}$ & $\begin{array}{l}\text { Not Carried } \\
\text { yet }\end{array}$ & Occasionally & $\begin{array}{c}\text { Carried } \\
\text { regularly }\end{array}$ & $\begin{array}{l}\text { Not Carried } \\
\text { yet }\end{array}$ & Occasionally \\
\hline RMDP/PBMC/ICB01 & & $\sqrt{ }$ & & & & $\sqrt{ }$ & & & $\sqrt{ }$ \\
\hline RMDP/PBMC/ICB02 & & $\sqrt{ }$ & & & & $\sqrt{ }$ & & & $\sqrt{ }$ \\
\hline RNDP/LCB/PBM1 & & $\sqrt{ }$ & & & & $\sqrt{ }$ & & & $\sqrt{ }$ \\
\hline RNDP/LCB/PBM2 & & $\sqrt{ }$ & & & & $\sqrt{ }$ & & & $\sqrt{ }$ \\
\hline RNDP/LCB/PBM3 & & $\sqrt{ }$ & & & & $\sqrt{ }$ & & & $\sqrt{ }$ \\
\hline RNDP/LCB/PBM4 & & $\sqrt{ }$ & & & & $\sqrt{ }$ & & & $\sqrt{ }$ \\
\hline RNDP/ICB/HN & & & $\sqrt{ }$ & & $\sqrt{ }$ & & & $\sqrt{ }$ & \\
\hline Total No & 0 & 6 & 1 & 0 & 1 & 6 & 0 & 1 & 6 \\
\hline
\end{tabular}

Table 5. Service delivery of contractor; road roughness and SDI survey, weigh bridge installation and traffic data.

\begin{tabular}{|c|c|c|c|c|c|c|c|c|}
\hline \multirow{2}{*}{ Contract name } & \multicolumn{3}{|c|}{ Road roughness and SDI survey } & \multicolumn{3}{|c|}{$\begin{array}{l}\text { Weighbridge installation and axle load } \\
\text { control }\end{array}$} & \multicolumn{2}{|c|}{ Maintaining traffic data } \\
\hline & $\begin{array}{l}\text { Carried out as per } \\
\text { specification }\end{array}$ & Not at all & $\begin{array}{l}\text { Carried not } \\
\text { regularly }\end{array}$ & Installed & $\begin{array}{c}\text { Not } \\
\text { installed }\end{array}$ & $\begin{array}{l}\text { In process of } \\
\text { installation }\end{array}$ & Yes & No \\
\hline RMDP/PBMC/ICB01 & & & $\sqrt{ }$ & $\sqrt{ }$ & & & & $\sqrt{ }$ \\
\hline RMDP/PBMC/ICB02 & & & $\sqrt{ }$ & $\sqrt{ }$ & & & & $\sqrt{ }$ \\
\hline RNDP/LCB/PBM1 & & & $\sqrt{ }$ & & $\sqrt{ }$ & & & $\sqrt{ }$ \\
\hline RNDP/LCB/PBM2 & & & $\sqrt{ }$ & & $\sqrt{ }$ & & & $\sqrt{ }$ \\
\hline RNDP/LCB/PBM3 & & & $\sqrt{ }$ & & $\sqrt{ }$ & & & $\sqrt{ }$ \\
\hline RNDP/LCB/PBM4 & & & $\sqrt{ }$ & & $\sqrt{ }$ & & & $\sqrt{ }$ \\
\hline RNDP/ICB/HN & & & $\sqrt{ }$ & & $\sqrt{ }$ & & & $\sqrt{ }$ \\
\hline Total & 0 & 0 & 7 & 1 & 6 & 0 & 0 & 7 \\
\hline
\end{tabular}


Role of Road Agency

The analysis of level of service effectiveness concludes that enforcement of the contracts was not strong. So, it shows that the contract administration from the DoR side is weak. Result of survey among the Engineers working in the PBM contract regarding weak contract administration shown in Figure 10. 27\% says that it is because of lack of willingness and motivation. 53\% of road agency says that they have the lack of proper knowledge on performance based maintenance and management. Similarly, 20\% sticks to SMD process and they believe that Department of Road should stick with SMD process rather than PBM contracts.

So, DoR's experience with performance-based contracts has not been fully positive, as they have faced a number of problems in implementation. These problems are in large part related to disputes between DoR and contractors regarding the responsibilities of the different parties. The major causes of the dispute are the quantities of the backlog maintenance, road deterioration due to increasing traffic volume, overloading vehicles. Furthermore Unforeseen situation, Frequent change of the DoR personnel, delay in budget are also other hindrance for the effective implementation of PBM in Nepal.

\subsection{Quality of Service}

The performance indicators like Surface Distress Index and Road roughness Index provides the basis for the comparison of level of quality service of the PBM roads with the same roads with the maintenance practice based on the SMD practices. The data published by the HMIS unit is the basis for analyzing this section. The Table 6 listed the time series data of IRI of the project implemented under the Performance Based Maintenance Contract. From Year 2001 to 2005, Maintenance is based on SMDP and From Year 2006 to 2010, PBMC implemented in the road.

Figure 11 shows that time series data in the project road during the SMDP process reflects somehow uniformity in the road roughness index, as all the roads are in the Fair pavement condition (IRI between 4 and 6). So the minimum performance standard of IRI expected during the performance based maintenance period is the fair

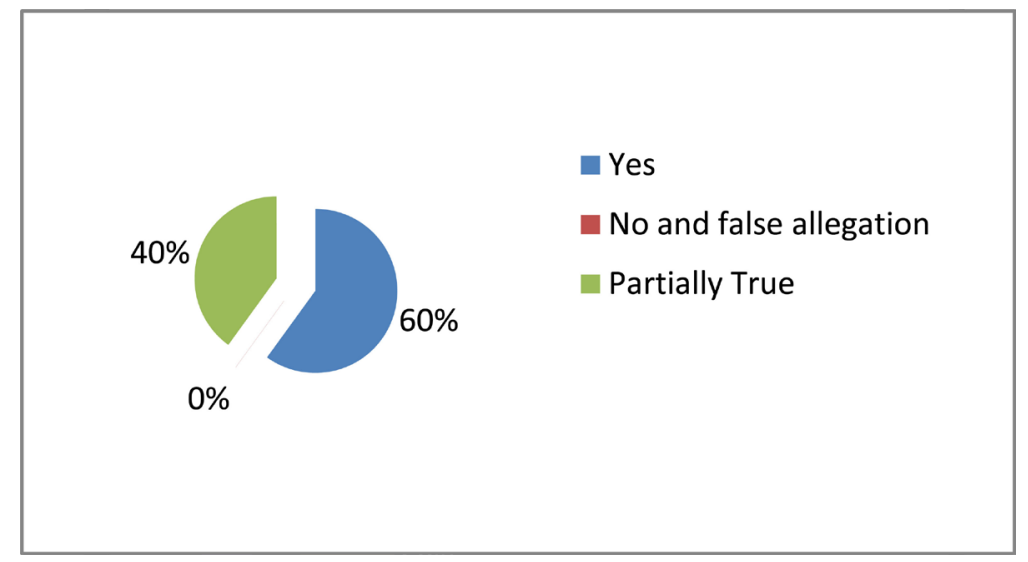

Figure 9. Attitude of contractor.

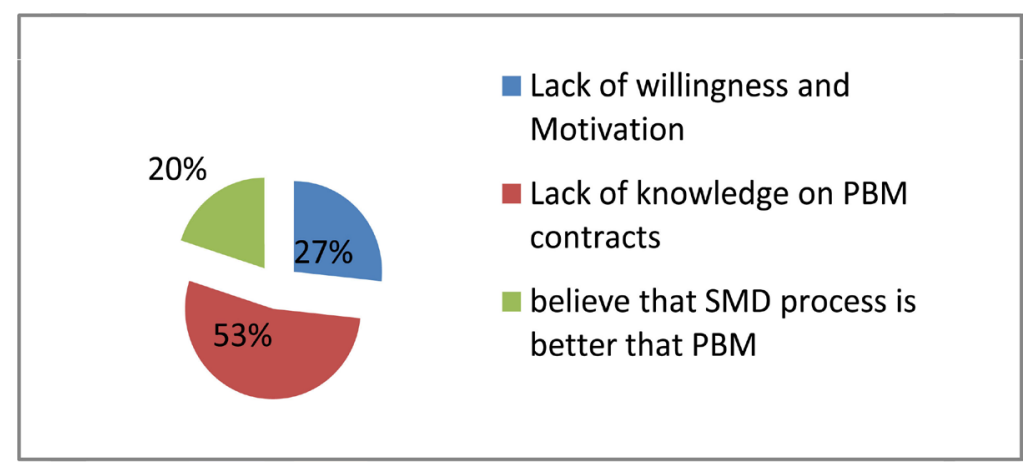

Figure 10. Attitude of road agency. 
Table 6. Time series data of IRI [16].

\begin{tabular}{|c|c|c|c|c|c|c|c|c|c|c|}
\hline \multirow{3}{*}{$\begin{array}{c}\text { Contract Name } \\
\text { Year }\end{array}$} & \multicolumn{10}{|c|}{ Road Roughness Index } \\
\hline & \multicolumn{5}{|c|}{ During SMDP } & \multicolumn{5}{|c|}{ During PBMC } \\
\hline & 2001 & 2002 & 2003 & 2004 & 2005 & 2006 & 2007 & 2008 & 2009 & 2010 \\
\hline RMDP/PBMC/ICB01 & 4.63 & 5.06 & 5.49 & 5.63 & 5.77 & 5 & 8.39 & 7.35 & 11.11 & 11.11 \\
\hline RMDP/PBMC/ICB02 & 4.61 & 5.08 & 5.56 & 5.41 & 5.27 & 5 & 10.2 & 7.11 & 11.02 & 11.02 \\
\hline RNDP/LCB/PBM1 & 4.61 & 4.59 & 4.58 & 4.58 & 4.6 & 4.87 & 5.68 & 5.43 & 8.9 & 8.9 \\
\hline RNDP/LCB/PBM2 & 4.72 & 4.93 & 5.15 & 4.95 & 4.76 & 5.23 & 5.78 & 6.19 & 10.05 & 10.05 \\
\hline RNDP/LCB/PBM3 & 4.79 & 5.09 & 5.4 & 5.1 & 4.8 & 5.43 & 6.11 & 6.8 & 9.82 & 9.82 \\
\hline RNDP/LCB/PBM4 & 4.72 & 5.13 & 5.54 & 5.14 & 4.73 & 5 & 8.12 & 6.48 & 9.8 & 9.8 \\
\hline
\end{tabular}

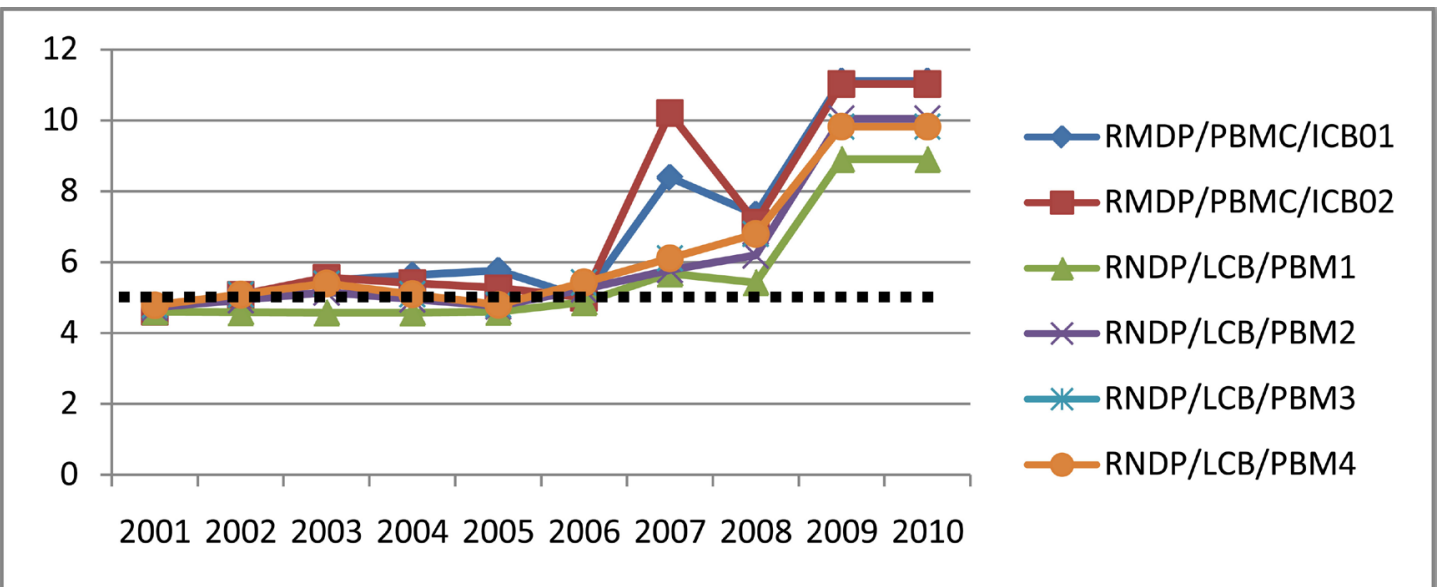

Figure 11. Time series of IRI in contract roads over time.

Table 7. Road roughness data [17].

\begin{tabular}{ccccccccccccc}
\hline Road Roughness & 1 & 2 & 3 & 4 & 5 & 6 & 7 & 8 & 9 & 10 & 11 \\
\hline Before PBM & 5.56 & 4.44 & 4.09 & 3.98 & 4.26 & 4.19 & 4.48 & 4.55 & 4.44 & 4.15 & 4.15 \\
After PBM & 7.89 & 7.32 & 6.52 & 6.50 & 7.17 & 6.90 & 7.81 & 8.53 & 7.43 & 6.62 & 6.98 \\
\hline Road Roughness & 12 & 13 & 14 & 15 & 16 & 17 & 18 & 19 & 20 & 21 & \\
\hline Before PBM & 3.66 & 3.99 & 3.99 & 4.19 & 4.06 & 4.19 & 4.52 & 4.07 & 4.25 & 4.01 & \\
After PBM & 5.45 & 5.81 & 6.12 & 6.60 & 5.93 & 6.33 & 7.28 & 6.23 & 6.41 & 6.21 \\
\hline
\end{tabular}

pavement condition. Once the Performance Based Maintenance Contract started in 2006, the road roughness of all the roads gradually increased. There was a sudden decrease in the road roughness between 2007 and 2008 in most of the project road; it is mainly due to implementation of the improvement works. Afterward, the road roughness was increased again beyond the performance standard expected during the Performance Based Maintenance Contract period from Year 2008 to 2010.

In the project road section, Mean Road Roughness Index for five years FY 2000/01 to FY 2004/05 before PBM implementation of the project area has been calculated. Likewise, the Mean Road Roughness Index for five years FY 2005/06 after PBM implementation of the project area has been calculated. The PBM project area of Hetauda-Narayani bridge has been excluded from this data analysis as the project was initiated only in April 2007. The data has been tabulated in Table 7

There are altogether 21 Numbers of samples of Road Roughness data. Based on that data, hypothesis has been created to verify whether the road conditions have been improved, degraded after implementation of Performance Based Maintenance and Management Contract.

Type of hypothesis: paired T-test for difference of means (analysis of service quality in term of road 


\section{roughness index)}

Diagnosis for selection

The sample sizes are equal $n_{1}=n_{2}(<30)$

The sample observations $\left(x_{1}, x_{2}, x_{3} \ldots, x_{n}\right)$ and $\left(y_{1}, y_{2}, y_{3} \ldots, y_{n}\right)$ are not completely independent but they are dependent in pairs. i.e. the pair of observations $\left(x_{1}, y_{1}\right),\left(x_{2}, y_{2}\right),\left(x_{3}, y_{3}\right) \ldots,\left(x_{\mathrm{n}}, y_{\mathrm{n}}\right)$ correspond to the $1 \mathrm{st}$, 2nd, 3rd ..., nth unit respectively.

Let, $x_{1}, x_{2}, x_{3} \ldots, x_{n}$ be the Road roughness index of the sample roads before implementation of Performance Based Maintenance and Management Contract.

Let, $y_{1}, y_{2}, y_{3} \ldots, y_{n}$ be the Road roughness index of the sample roads after implementation of Performance Based Maintenance and Management Contract.

Null Hypothesis: H0: $\mu x=\mu y$ or $d=0$ i.e. there is no significant difference between road roughness before and after implementation of Performance Based Maintenance and Management Contract.

Alternative Hypothesis: $\mathrm{H} 1: \mu x<\mu y$ or $d<0$ i.e. there is the increase in the road roughness after implementation of the Performance Based Maintenance and Management Contract.

\section{Test Statistics}

Under H0, the test statistic is, $t=d /\{S d / S Q R T n\}$

where, $d=$ Mean of the difference $=\sum \mathrm{d} / \mathrm{n}$

$d=x-y$ or $y-x=$ difference between two sets of observations

$(S d)_{2}=$ Sample variance of the difference $=1 / n-1 \sum(d-d) 2$

Test Statistic

$t=d /\{S d / S Q R T n\}=2.51 /[0.527 / S Q R T(21)]=21.79$

Critical Value:

\begin{tabular}{cccc}
\hline S.N. & Level of Significance & Degree of Freedom & Tabulated Value \\
\hline 1 & $1 \%$ & 20 & 2.528 \\
\hline
\end{tabular}

\section{Decision:}

Since, calculated value of $t$ is greater than the tabulated value of $t$ at $1 \%$ level of significance, $\mathrm{H} 0$ is rejected and hence $\mathrm{H} 1$ is accepted. Therefore we can conclude that there is increase in road roughness of the road after implementation of Performance Based Maintenance and Management Contract.

Discussion: The time series data during the SMDP process from Year 2001 to 2002 shows that SMDP process was well implemented in all the road section as the road conditions were fair between that period. The performance standard based on IRI in the initial road condition survey expects the road to be in fair condition (IRI between 4 to $6 \mathrm{~m} / \mathrm{km}$ ) during the performance based maintenance period. It was essential immediately to conduct the periodic maintenance work in these road sections under SMDP process at the early 2005. But in most of these roads the improvement works under Performance Based Maintenance Contract only completed at the mid 2007. This has show the backlog in the maintenance work and that was one of the reason behind worsens the road condition. The contract modality of performance Based Maintenance Contract is based on the input based bill of quantities, and any increase in the backlog has created the increase in the pretreatment work before the improvement work. The modality of the contract under Performance Based Maintenance Contract was not able visualize that risk. In overall, the contractor was not able to maintain the performance standard based on IRI. Another reason for de Terioration of road pavement is the overloaded traffic and increasing traffic volume in the later part of the year. The project pavements are design only for 10 ton axle load, while the truck transport vehicles with 15 to 20 ton axle loads ply on these roads. Although contract have the provision of axle load control through installation of weigh bridge, road the contractors could not succeed in operating the weighing machines due to lack of support from law enforcing authorities.

\subsection{Cost Analysis}

One of important aspects for the evolution of the performance based contracts is the cost savings. Cost comparison of the PBM roads with the same roads with the maintenance based on the SMD process is analyzed in this section. 


\subsubsection{Cost Distribution Analysis}

The Performance based management and maintenance contracts in Nepal generally comprises of General works, Maintenance works, Improvement works, Emergency works and Day works. The cost distribution patterns of the project based on the Performance Based Maintenance and Management Contract is shown in Table 8 and Figure 12.

The pattern shows improvement work component varies from the minimum of $67.32 \%$ of total contract amount in project RNDP/LCB/PBM3 to the maximum of $85.18 \%$ of total contract amount in project RNDP/ ICB/HN. The maintenance cost pattern shows the maximum percentage of $19.95 \%$ of contract amount in project RMDP/PBMC/ICB02 to minimum of $0.7 \%$ of total contract amount in project RNDP/ICB/HN. The cost data shows that in only RMDP/PBMC/ICB02, Maintenance work contains a significant percentage and other projects constituents less than $8 \%$.

Table 8. Cost distribution patterns of PBMC in Nepal.

\begin{tabular}{|c|c|c|c|c|c|c|c|}
\hline $\begin{array}{l}\text { Name of the } \\
\text { contract }\end{array}$ & Road & $\begin{array}{c}\text { General } \\
\text { works (NRs) }\end{array}$ & $\begin{array}{l}\text { Maintenance } \\
\text { works (NRs) }\end{array}$ & $\begin{array}{c}\text { Improvement } \\
\text { works including } \\
\text { additional works } \\
\text { (NRs) }\end{array}$ & $\begin{array}{c}\text { Emergency } \\
\text { works (NRs) }\end{array}$ & $\begin{array}{l}\text { Day works } \\
\text { (NRs) }\end{array}$ & $\begin{array}{l}\text { Total contract } \\
\text { amount (NRs) }\end{array}$ \\
\hline \multirow{2}{*}{ RMDP/PBMC/ICB01 } & Chaurahawa-Phuljor & $13,635,818.2$ & $1,464,709.091$ & $59,288,453.96$ & $1,114,821.82$ & $604,090.909$ & 76107894 \\
\hline & (\% of total contract amount) & 17.92 & 1.92 & 77.90 & 1.46 & 0.79 & 100 \\
\hline \multirow{2}{*}{ RMDP/PBMC/ICB02 } & Phuljor-Pathalaiya & $3,814,363.64$ & $13,723,977.27$ & $49,359,364.28$ & $1,380,066.55$ & $509,011.364$ & $68,786,783.1$ \\
\hline & (\% of total contract amount) & 5.55 & 19.95 & 71.76 & 2.01 & 0.74 & 100 \\
\hline \multirow{2}{*}{ RNDP/LCB/PBM1 } & Kohalpur-Bhurigaon & $3,688,000$ & $2,938,000$ & $37,518,600$ & $2,961,700$ & 640,950 & $47,747,250$ \\
\hline & (\% of total contract amount) & 7.72 & 6.15 & 78.58 & 6.20 & 1.34 & 100 \\
\hline \multirow{2}{*}{ RNDP/LCB/PBM2 } & Bhurigaon-Lamki & $2,488,000$ & $2,777,400$ & $38,031,705$ & $3,127,900$ & 863,150 & $47,288,155$ \\
\hline & (\% of total contract amount) & 5.26 & 5.87 & 80.43 & 6.61 & 1.83 & 100 \\
\hline \multirow{2}{*}{ RNDP/LCB/PBM3 } & Lamki-Attariya & $4,790,000$ & $3,062,500$ & $33,301,200$ & $7,437,725$ & 876,600 & $49,468,025$ \\
\hline & (\% of total contract amount) & 9.68 & 6.19 & 67.32 & 15.04 & 1.77 & 100 \\
\hline \multirow{2}{*}{ RNDP/LCB/PBM4 } & Attariya-Gaddachowki & $3,650,000$ & $3,688,500$ & $39,561,900$ & $2,350,375$ & 730,850 & 49,981,625 \\
\hline & (\% of total contract amount) & 7.30 & 7.38 & 79.15 & 4.70 & 1.46 & 100 \\
\hline \multirow{2}{*}{$\mathrm{RNDP} / \mathrm{ICB} / \mathrm{HN}$} & Hetauda-Narayani & $7,445,050$ & $1,096,524$ & $119,192,235.4$ & $7,157,353.5$ & $5,038,906.95$ & $139,930,070$ \\
\hline & (\% of total contract amount) & 5.32 & 0.78 & 85.18 & 5.11 & 3.60 & 100 \\
\hline
\end{tabular}

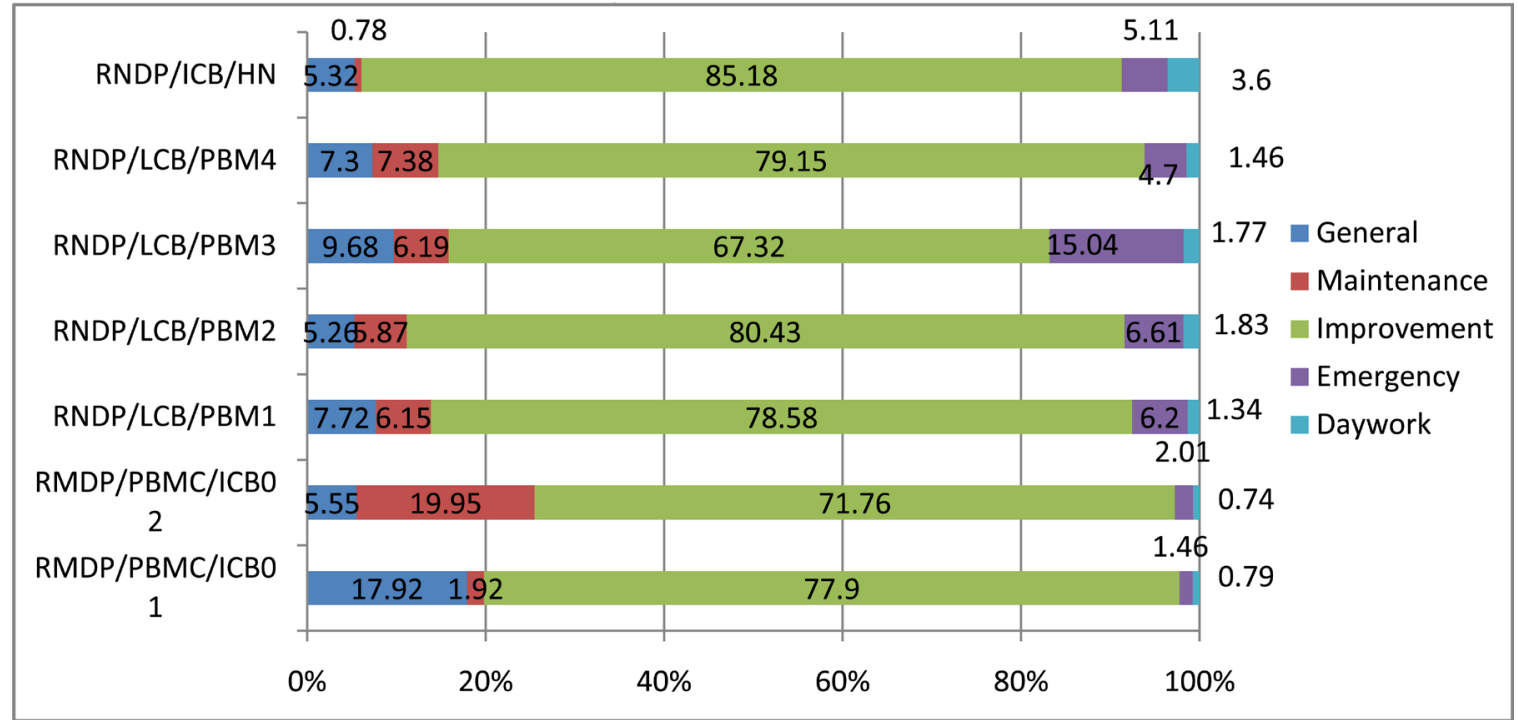

Figure 12. Cost distribution patterns. 
Discussion: the rationale behind the cost distribution pattern analysis is to analyze the bidding behavior of the contractor. Improvement work generally consists of the surface dressing work in all of the contracts. The improvement works have to complete within 18 months, in overall, $75 \%$ to $90 \%$ of the contract amount has to be spent in first 18 months of the five year project. This shows the front loading behavior of the contractor. Low bidding with regard to the maintenance phase of the PBM projects meant that there was little incentive for the contractor to retain an interest in the project. The contractors were not aware of the risk in the maintenance part of the contract. But the real situation is the condition has caused the objective with the PBM project formulated was not achieved. Such front loading is mitigated through the specifying of minimum threshold amount or contract values that must be included for the monthly payments for the required maintenance period.

\subsubsection{Cost Efficiency Analysis}

Comparison of the maintenance cost based on the SMD practice and PBM is carried out. In SMD practice, Total annual maintenance costs sum of the routine maintenance, routine bridge maintenance and the recurrent maintenance cost. Routine maintenance cost and routine bridge maintenance cost is computed using the norms and rate of the concerned maintenance divisions at that period. Recurrent Maintenance cost is computed using the rate of the similar nature of the neighboring road section. The total maintenance cost for the whole period based on SMD practice is computed. Reviewing the trend of the Contractor bidding behavior average discount of $40 \%$ is applied to the total maintenance cost based on SMD. Likewise, for Performance Based Maintenance Contract, whole maintenance cost for each of project for overall project period is calculated. The overall total cost situation for each of the practice is presented in Table 9 .

The cost comparison made between the two shows that Performance Based Maintenance Contracts are more cost saving than the SMD Maintenance practices. The minimum cost saving of $0.82 \%$ is observed in contract RMDP/PBMC/ICB02 and the highest cost saving of $54.08 \%$ of maintenance cost is observed in contract RMDP/PBMC/ICB01. The cost saving from $31.6 \%$ to $42.05 \%$ have been observed in the other projects. This does not considered the saving of overhead of each year procurement which have to be done in the case of SMD Process.

\section{Conclusions}

It was concluded that that contractors had not performed well in any of the six components for analyzing their performance. Likewise, it was found that road agency was weak in administrating the contracts. There was no improvement in the service quality of the road in term of road roughness of the road after the implementation of Performance Based Maintenance and Management Contract. Cost distribution patterns of the project road show that improvement works occupy the bigger proportion of the contract amount and that maintenance works constitute lesser proportion of contract amount. This concludes the front loading behavior of the contractor and least preference of the contractor in the maintenance part. Cost comparison between the maintenance based on PBM and SMD practices shows that there is a significant cost saving from the Performance Based Maintenance and Management Contract. Implementation of PBMC was not successful in Nepal as Road Asset condition was not maintained to performance standard. One of the reasons is the weak service delivery of contract or alongside weak contract enforcement from the road agency.

Table 9. Cost efficiency analysis.

\begin{tabular}{|c|c|c|c|c|c|c|c|}
\hline \multirow{3}{*}{ Name of road } & \multirow{3}{*}{$\begin{array}{l}\text { Length } \\
(\mathbf{K m})\end{array}$} & \multicolumn{5}{|c|}{ Maintenance cost for five years } & \multirow{3}{*}{$\begin{array}{c}\begin{array}{c}\text { Cost } \\
\text { saving }\end{array} \\
(\%)\end{array}$} \\
\hline & & \multicolumn{3}{|c|}{ SMD practice } & \multicolumn{2}{|c|}{ PBM } & \\
\hline & & $\begin{array}{l}\text { Total cost } \\
\text { (NRs) }\end{array}$ & $\begin{array}{l}\text { Dicounted cost } \\
\text { (NRs) }\end{array}$ & Cost/Km & $\begin{array}{l}\text { Total cost } \\
\text { (NRs) }\end{array}$ & Cost/Km & \\
\hline Chaurahawa-Phuljor & 75 & $24,742,995$ & $14,845,797.00$ & $197,943.96$ & $1,464,709.09$ & $19,529.5$ & 54.08 \\
\hline Phuljor-Pathalaiya & 75 & $23,191,828$ & $13,915,096.80$ & $185,534.62$ & $13,723,977.27$ & $182,986.4$ & 0.82 \\
\hline Kohalpur-Bhurigaon & 56 & $15,160,909$ & $9,096,545.40$ & $162,438.31$ & 2,938,000.00 & $52,464.3$ & 40.62 \\
\hline Bhurigaon-Lamki & 52 & $15,481,114$ & $9,288,668.40$ & $178,628.24$ & $2,777,400.00$ & $53,411.5$ & 42.05 \\
\hline Lamki-Attariya & 50 & $14,849,506$ & $8,909,703.60$ & $178,194.07$ & $3,062,500.00$ & 61,250 & 39.37 \\
\hline Attariya-Gaddachowki & 46.48 & $12,989,031$ & $7,793,418.60$ & $167,672.52$ & $3,688,500.00$ & $79,356.7$ & 31.6 \\
\hline
\end{tabular}


Finally following recommendations are made for the effective implementation of the Performance Based Maintenance and Management Contracts in Nepal.

1) The present contract modality of schedule of rate contract breaking into various improvements, emergencies and maintenances was not realistic instead. The contract should be made into lump sum output based contract like Design Build with more risk to the contractor. The more recent OPRC contract can be a good option.

2) Proper discussion with time frame among all of the stakeholders to modify and develop the PBMC document compatible with Nepali Environment and its implementation. Service quality indicators, inspection format, penalty reduction provision specified in PBM contracts are not quite compatible to Nepali Environment and so it needs modification.

3) Role of the consultant should be sought for execution of the Performance Based Maintenance Contract.

4) Proper capacity development in the form of extensive training among all stakeholders including contractor. Institutional strengthening component can be added in the PBM contracts. Separate PBM unit under Maintenance Branch of Department of Road can be established which will regularly monitor the PBM contracts.

\section{Acknowledgements}

I would like to thank Department of Roads, Kathmandu for funding the research work. This is a part of my dissertation in Msc Construction Management, Pokhara University, Nepal.

\section{References}

[1] DoR (2013) Road Statistics of Strategic Road Network. Department of Roads, Kathmandu

[2] DoR (2013) Road Condition Survey Data. Department of Roads, Kathmandu.

[3] DoR (2007) Sector Wide Road Programme and Priority Investment Plan. Department of Roads, Kathmandu.

[4] DoR (2006) Program Document, Strengthened Maintenance Divisions Program, Project Phase III July 2002-June 2006. Department of Roads, Kathmandu.

[5] DoR (2005) Contract Agreement Volume I and II, Conditions of Contract and Specification, Performance Based Maintenance Component (MRM Km 218+000-293+000) Contract No, RMDP/PBMC/ICB01. Department of Roads, Kathmandu.

[6] DoR (2005) Review and Strategic Assessment of the Strengthened Maintenance Divisions Program. Final Mission Report, Department of Roads, Kathmandu.

[7] William, H. (2009) Performance Based Contracting for Maintenance, a Synthesis of Highway Practice. Transportation Research Board, Washington DC

[8] Gunter, Z. (2011) Cutting Costs and Improving Quality through Performance Based Management and Maintenance Contracts-The Latin American and OECD Experiences. University of Birmingham, Birmingham, Senior Road Executives Programme April 2011.

[9] Sultana, M., Rahman, A. and Chowdhary, S. (2012) An Overview of Issue to Be Consider before Introducing Performance Based Road Maintenance Contract. International Journal of Civil, Environmental, Structural, Construction and Architectural Engineering, 6, 137-142.

[10] DoR (2005) Contract Agreement Volume 2, Conditions of Contract Specification, Performance Based Maintenance Component (MRM Km 824+280-880+280) Contract No, RNDP/LCB/PBM/1. Department of Roads, Kathmandu.

[11] DoR (2005) Contract Agreement Volume 2, Conditions of Contract Specification, Performance Based Maintenance Component (MRM Km 880+280-932+280) Contract No, RtNDP/LCB/PBM/2. Department of Roads, Kathmandu

[12] DoR (2005) Contract Agreement Volume 2, Conditions of Contract Specification, Performance Based Maintenance Component (MRM Km 932+280-982+280) Contract No, RNDP/LCB/PBM/3. Department of Roads, Kathmandu

[13] DoR (2005) Contract Agreement Volume 2, Conditions of Contract Specification, Performance Based Maintenance Component (MRM Km 982+280-1029+020) Contract No, RNDP/LCB/PBM/4. Department of Roads, Kathmandu

[14] DoR (2005) Contract Agreement Volume I and II, Conditions of Contract and Specification, Performance Based Maintenance Component (MRM Km 293+000-367+630) Contract No, RMDP/PBMC/ICBC02. Department of Roads, Kathmandu

[15] Piñero, J.C. (2003) A Framework for Monitoring Performance-Based Road Maintenance. PhD Dissertation, Virginia Polytechnic Institute and State University, Blacksburg.

[16] DoR (2010) Surface Distress survey and Road Roughness survey Data , 2001/02, 2002/03, 2003/04, 2004/05, 2005/06, 
2006/07, 2007/08, 2008/09, 2009/10 Highway Management Information System Unit. Department of Roads, Kathmandu.

[17] DoR (2010) Integrated Annual Road Maintenance Plan (IARMP) FY 2004/05, FY 2005/06, FY 2006/07, FY 2007/08, FY 2008/09, FY 2009/2010 Maintenance Branch. Department of Roads, Kathmandu. 